\title{
Identity according to Francis Fukuyama: An obstacle to the end of history
}

\author{
FRANTIŠEK PAĎOUR
}

\section{sciendo}

Politics in Central Europe (ISSN: 1801-3422)

Vol. 16, No. 1

DOI: $10.2478 /$ pce-2020-0015

\begin{abstract}
This review essay focuses on Francis Fukuyama's book Identity: The Demand for Dignity and the Politics of Resentment, which was published in 2018. The text emphasises placing Fukuyama's new publication in the context of his multi-year work for its correct interpretation. Fukuyama's conception of the human soul is analysed in confrontation with contemporary issues of liberal democracy. It mentions other authors criticisms of Fukuyama's work and, at the same time, it is defended by Fukuyama himself. The text can be seen as an introduction to Francis Fukuyama's reasoning regarding the modern problems of liberal democracy and as an attempt to understand his unsuccessful prediction of the end of history. The central theme of the text is the concept of identity, which Fukuyama describes as a source of conflicts and friction areas in modern societies. Fukuyama's findings are supplemented by the findings of other authors and current world events.
\end{abstract}

Keywords: Francis Fukuyama, Thumos, Identity, Politics of Resentment.

The Neohumanist ${ }^{1}$ Francis Fukuyama became known mainly due to his article The End of History? (Fukuyama 1989) published in 1989 in National Interest, which was elaborated into a book in 1993 called The End of History and the Last

1 Similar to humanists in the $14^{\text {th }}$ to $16^{\text {th }}$ centuries, Fukuyama refers to historical, traditional philosophy (especially to Plato), responding to various modern speculative social science approaches. This approach is applied in the context of both historical and contemporary social sciences and is therefore described as a Neohumanist. At the same time, Fukuyama is oriented towards man and his peaceful development, which in his opinion is supposed to ensure the phenomenon of the second half of the $20^{\text {th }}$ century and the beginning of the $21^{\text {st }}$ century - liberal democracy. 
Man (Fukuyama 1993). These publications reflect the atmosphere of the late 1980s and early 1990s, when, after forty years of the Cold War, the Western bloc represented by liberal democracy and the market economy managed to overcome the Eastern bloc, which symbolised the non-democratic communist order. After the triumph of liberal democracy, the winning camp perceived this victory as absolute, and it was expected that liberal democracy and the market economy would spread throughout the world as an ideal of the social and political order of states. Francis Fukuyama also succumbed to this atmosphere, predicting in the mentioned publication that the history of liberal democracy as a constant conflict of religious, ideological or political approaches that accompanied humankind until it reached a liberal democracy, which could no longer find an equal competitor, had come to an end. For Fukuyama, this moment means the end of history.

Francis Fukuyama ranks among macro-historians, looking at the course of history as a progressive whole, not examining the details of a particular historical event, but looking for common phenomena that characterises each period and demonstrates them at major historical events, such as the Great French Revolution, World War I, the rise of fascism in Europe, terrorist attacks, etc. It's evident that Fukuyama has popularised his publications successfully, making him widely read outside the academic community and able to attract a wide array of readers interested in world politics. He is doing well mainly based on the choice of „big topics“. However, this fact doesn't deny the quality of academic work, which is rated higher than that of Fukuyama's best-known critic and opinion opponent Samuel Huntington in his popular publication Clash of Civilisations (Huntington 1996). In the case of Fukuyama, the operationalisation of terms is at a good level. Unlike Huntington, he provides his own grasp of terms to avoid misinterpretation.

Fukuyama's research method in the case of new and previous works can be described as qualitative. He tries to investigate themes in depth and find the causes of significant phenomena. Fukuyama's research is based on the search for the essences of phenomena instead of a quantitative collection of large amounts of information and calculating conclusions by mathematical methods. The reader can evaluate Fukuyama's work critically in terms of its liberal-democratic normativity. However, this fact is somewhat predictable, as Fukuyama is perceived as an „advocate“ of liberal-democratic universalism of the late $20^{\text {th }}$ century (Fukuyama 1991: $659-664$ ). Fukuyama's new publication will find many critics amongst left-wing postmodernists as well as right-wing nationalists. Nevertheless, Fukuyama is trying to find a consensual solution to find unity in fundamental issues amongst opposing social segments (identities - see below).

Fukuyama perceives history through the lens of the Hegelian concept of progress, as mentioned above, history is perceived as a whole, which, based on 
reason, human work and ideas, is still directed towards the ideal and ultimate organisation of humanity. Fukuyama advocates this positive historical progress with an empirical view of the course of history, and humanity is gradually succeeding in achieving a more free and peaceful arrangement. However, history's progress in Fukuyama's conception doesn't neglect the role of warfare and conflict. For Fukuyama, this progress is characterised by historical conflicts that have driven humankind to progress.

According to Fukuyama, historical conflicts are the epoch-making conflicts between Islam and Christianity, the dispute between the power of the sovereign and the Church, the conflict within the Christian Church, the conflict between the power of the sovereign and the will of the people. All of these historical conflicts have in common that in either case there was no clear winner, the dispute had cooled down, or power and sphere of influence had been divided among the competing parties, and therefore another conflict could have arisen, allowing history to continue as a permanent conflict. However, the difference came during, and especially at the end, of the twentieth century, when democracy and liberalism triumphed over non-democratic, firstly fascist and later communist regimes. These non-democratic regimes have ceased to be an equal competitor to liberal democracy. According to Fukuyama, such liberal democracy has lost whatever rival, the course of history has lost the always-present conflict, bringing history to its end.

It should be added that the events of the 1990s and the beginning of the $21^{\text {st }}$ century refuted Fukuyama's prediction and optimism about the dominance of liberal democracy to a certain extent. One of the first arguments against Fukuyama's claim was the war conflict in Yugoslavia, which his critics (Maershaimer neo-realists, Huntington) mentioned most often. ${ }^{2}$ Similarly, many other events occurring in the following years didn't really support Fukuyama's predictions. The terrorist attacks in the US on September $9^{\text {th }}, 2001$, also other terrorist attacks were not supposed to have a place in a world in which liberal democracy was supposed to spread universally. Instead, these events were arguments for Fukuyama's best-known critic, S. Huntington, and his work Clash of Civilisations (Huntington 1997). The modern conflict of religious fundamentalism with Western globalism could be considered, in a simplified interpretation, to bust Fukuyama's hypotheses. According to Fukuyama, liberal democracy was supposed to spread globally, with no competition; and enhanced Islamism wasn't foreseen.

As mentioned above, Fukuyama admits a conflict as a part of society's way towards better tomorrows. Therefore, Fukuyama was not a critic of a US armed intervention. However, even further developments didn't suggest that Fukuy-

2 E-International Relations (2018) Huntington vs. Mearsheimer vs. Fukuyama: Which Post-ColdWar Thesis is Most Accurate? [cit. 17/05/2019] Available online at: https://www.e-ir.info/2018/04/22/huntington-vs-mearsheimer-vs-fukuyama-which-post-cold-war-thesis-is-most-accurate/(24 February 2020). 
ama's predictions would be fulfilled. Other problems for the liberal-democratic world order also appeared at the last turn of the decade; this time within the Western liberal-democratic world. Specifically, it's the rise of right-wing nationalism across states. The phenomenon that hindered the path to liberal-democratic universalism, which was to be overcome by the past, reappeared. Donald Trump being elected as president of the United States, a rise in the preferences of radical right-wing politicians in Western and especially Central and Eastern Europe, can be mentioned randomly. Deficiencies in the democratic functioning of countries in Central, and Eastern Europe, such as the introduction of „illiberal“ democracy by Viktor Orbán in Hungary ${ }^{3}$ or the flaws in the democratic rule of law in Poland ${ }^{4}$.

However, similar trends are also evident in western Europe. Examples include strengthening right-wing nationalists in Italy $^{5}$, nationalist populism on the rise in Austria ${ }^{6}$ and many other countries. After all, Russia's attempt to introduce liberal democracy has also failed, and this superpower has slipped into some form of non-democratic regime under Vladimir Putin ${ }^{7}$. The People's Republic of China (PRC) has successfully responded to economic globalism and liberalism, but its political regime didn't go hand in hand with economic liberalisation and indeed can't be described as democratic. The Communist Party of the PRC is taking the opposite path, skilfully using modern technology to tighten control and restrict the population's freedom. ${ }^{8}$ Since Donald Trump was elected as the US president, there has also been a global rise in protectionism and a partial return to real politics at the level of the great powers and some smaller states. ${ }^{9}$ Although the Russian annexation of Crimea has created a rare consensus on the topic of foreign policy within the Western states on the imposition of economic sanctions on Putin's non-democratic regime, these events have certainly not added to the worldwide legitimacy of liberal democracy. The interpretation of sanctions by state-controlled media and top politicians for Russian citizens

3 Available online at: https://freedomhouse.org/report/modern-authoritarianism-illiberal-democracies(24 February 2020).

4 Available online at: https://www.politico.eu/article/poland-democracy-failing-pis-law-and-justice-media-rule-of-law/(24 February 2020).

5 Available online at: https://www.theguardian.com/world/2018/dec/01/italians-first-matteo-salvini-the-league-rise-rightwing-populism(24 February 2020).

6 Available online at: https://www.usnews.com/news/best-countries/articles/2018-07-05/austrias-influential-rise-to-fuel-far-right-movement-in-europe(24 February 2020).

7 Available online at: https://www.foreignaffairs.com/articles/china/2018-10-02/how-russia-and-china-undermine-democracy(24 February 2020).

8 Available online at: https://www.washingtonpost.com/gdpr-consent/?destination=\%2fnews\%2fthew orldpost\%2fwp\%2f2018\%2f11\%2f27\%2fchina-authoritarian\%2f\%3f \& utm_term=.d58e2ed0138d (24 February 2020).

9 Available online at: https://foreignpolicy.com/gt-essay/understanding-trumps-trade-war-china-trans-pacific-nato/(24 February 2020). 
and citizens of Russian allied states creates a negative discourse regarding the Western liberal-democratic system. ${ }^{10}$ Although the sanctions affect Russia on an economic level to some extent, the social and political effect of sanctions is more of a deepening of the gap between „Eastern “ authoritarianism and „Western " democratic liberalism, rather than the desired convergence of the 1990s."

Fukuyama's predictions about the end of history and the worldwide victory of liberal democracy have many flaws, and his critics are packed with arguments against his claims. Fukuyama's work, therefore, had become much more damned as a rash attempt to predict liberal-democratic universalism from the 1990s, when, in a euphoric atmosphere, it seemed that after the defeat of the Eastern Bloc, liberal democracy would no longer have an equal rival and historical conflict was at its end. However, the radical condemnation and denial of Fukuyama's thoughts are caused by their simplified and misleading interpretation to some extent. All arguments against Fukuyama are no surprise to him, and he admits these pitfalls for liberal democracy in his work and defends them in the opening part of his book Identity: The Demand for Dignity and the Politics of Resentment.

For a proper understanding and analysis of the reviewed book Identity: The Demand for Dignity and the Politics of Resentment, as well as a basic introduction to Fukuyama's previous work is necessary. In his new publication, Fukuyama, to a certain extent, continues his End of History and at the same time, in the introductory part, provides a look back at his predictions and responds to their criticism. Fukuyama admits and describes the problems that liberal democracy is currently facing. He doesn't seek to defend the dominance of liberal democracy, which would have a considerable demagogic effect. However, in the opening part of the book, Fukuyama highlights the misunderstanding and misinterpretation of his previous work by his critics.

Hegel, from whose conception of history Fukuyama draws his inspiration, found the Prussian State to be the pinnacle of history. Similarly, based on Hegel's dialectics, Karl Marx found the ultimate historical conflict in the proletariat versus bourgeoisie, with the proletariat as the winner. For Fukuyama, the end of history is the victory of liberal democracy. According to his claim, humanity has nowhere else to go, and it's impossible to find a more ideal social and political order. Fukuyama predicted that by the triumph of liberal democracy of the 1990s, humankind is entering a "post-historical" phase in which the engine of progress - a conflict of different approaches - disappears. Fukuyama understands the end of history as the end of History (with a capital letter), but

10 Available online at:https://www.independent.co.uk/news/world/americas/us-politics/us-russia-sancions-latest-putin-trump-washington-moscow-a8503371.html(24 February 2020).

11 Available online at:https://foreignpolicy.com/2018/09/26/new-sanctions-wont-hurt-russia-putin-oligarchs-rusal-deripaska/(24 February 2020). 
that doesn't mean that it's a chronologically absolute state and that humanity cannot slip back from post-history to history.

The end of History in the form of a triumph of liberal democracy is therefore the highest degree of historical progress in the category of social, political and power organisation, but that doesn't mean that humanity will always live in the state of the End of History. At the same time, Fukuyama warns that if the problems that liberal democracy is facing continue and no ways are found to unite the various opposing groups inside and outside democracies, a return to a specific phase of history is possible. By returning to history is understood the decline of the world's influence of liberal democracy. It's precisely the identification and analysis of the causes of the problems of liberal democracy, as well as the attempt to remedy them that Francis Fukuyama focuses on in his book Identity: The Demand for Dignity and the Politics of Resentment.

The central concept behind Francis Fukuyama's previous work and Identity is the Greek term Thymos ${ }^{12}$ (English: Thumos). Fukuyama's book is based on Plato's conception of the human soul, which he described in the Constitution (Platón 1993). According to Plato and Fukuyama, the human soul consists of three components: desire, reason, and thumos. According to Plato, the first of the three components of the soul is desire. Desire is the emotional need of a man who blindly drives human lust. If desire were the only component of the soul, it's inevitable that a man lacking opinions and driven only by his desires, wouldn't make much progress. Human beings acting unreasonably, being subject to their desires, would surely clash in the dead ends of their interests from which there is no way out.

However, according to Plato, reason is the second component. Thanks to reason, one can control or regulate one's emotions to some extent. Therefore, the emotional need in the form of desire is complemented by reason, which seems to be largely behind human progress. However, reason alone wouldn't be enough for human progress and success. Indeed, many prominent women and men of human history wouldn't have become significant if they had no desire to do extraordinary things. However, this phenomenon is not only present in the elites who are mentioned as the creators of historical events, but it constructs the soul of all individuals who, to a varying degree and with the relationship of desire and reason, participate in the historical progress of humankind without realising it. Therefore, according to Plato, man is a longing and thinking being. These two components of the soul distinguish man from animals and cause the homo homini lupus ${ }^{13}$ state isn't society's only normative state, since man in his behaviour and decision is subject to reason and desire, not just instinct. However,

12 „3. Thumos, according to Plato“[cit. 01-03-2019] Available at: https://classicalwisdom.com/culture/traditions/tradition-thumos/ (24 February 2020).

13 A man is a wolf to another man 
this doesn't mean that one can't slip into this „natural state“ (as referred to by realists). Man's nature is longing and thinking, but that doesn't mean peace or war.

Therefore, desire is driven by human lust, which is directed by reason. For each individual, one of these components prevails to a different degree, or they're in equilibrium. For instance, an example of the relationship between these two components is the desire for an expensive car, which is yet guided by reason, calculating to determine whether such an investment pays-off or whether the individual has the resources. If the human soul consisted solely of desire, the individual would have thoughtfully bought an expensive car, but would soon find out that such investment would ruin him or would create such debt, whereby he's unable to make repayments. Therefore, he loses all his property or his freedom. However, happiness is a desire balanced by reason. Though a reasoning man longs for an expensive car, at the same time, within a short time and almost automatically, he calculates in his mind, based on which he realises that such a calculation is disadvantageous for him and doesn't make sense.

As mentioned above, the human soul consists of three parts. Desire is complemented with reason, and conversely, reason completes desire, and these two components are further complemented with or determined by a third component, thumos. Thumos is central to Fukuyama in his thinking about society's political decision-making. According to Fukuyama, thumos was behind the birth and spread of democracy in the $19^{\text {th }}$ and $20^{\text {th }}$ centuries. It also causes the phenomenon of so-called identities, which is described in the reviewed publication Identity: The Demand for Dignity and the Politics of Resentment. Paradoxically, and to some extent, these identities are behind the current problems that democracies are facing worldwide. The paradox, therefore, is that the same thumos that was behind the birth of democracy is today a serious threat and an obstacle to democracy.

The third component of the human soul, thumos, was associated with warriors in traditional societies. Thumos captures their inner pride, which is, however, manifested towards the outside world as a means of external recognition. Therefore, it includes both internal and external dimensions. The satisfaction of the inner dimension of the thumos occurs through its outer dimension. Thumos represents the perception of oneself towards the outside world; it's internal self-determination concerning the whole. In other words, how I perceive myself based on how society perceives me. A good example is the model of an ancient warrior - a hero who was able to pay with his life to maintain his pride. If a warrior was disgraced or challenged to a duel of life and death, a warrior didn't hesitate to take part in such a duel, even though he knew he could lay down his life in the duel. Yet, the pride and respect of society was a higher value for a warrior than his own life, as it determined his existence and self-concept.

His pride, which determined his personality vis-à-vis the whole, was for him the highest value for which he was recognised and respected by society. Respect 
for society and recognition of heroic status satisfied the warrior's thumos. Thumos can, therefore, be perceived as a need for the individual's recognition or identification by the outside world. Based on thumos, an individual perceives their position in the world. However, ordinary citizens, subjects, workers didn't have this value in traditional societies. Their role in society was given since birth and remained the same throughout their lives. If someone was born into a shepherd's family, he inherited this livelihood from his parents and exercised it throughout his life. The shepherd was satisfied with this role because he grew up as a shepherd and was a shepherd; having no other demands and needs than for supporting himself and his family. He didn't address aspects such as pride or respect from society; his role was to shepherd sheep and support his family. He left pride and respect to the warriors. Demands of thumos of ordinary people were therefore on lower level then in the cases of warriors.

According to Fukuyama, more intensive demands of thumos begins to appear among ordinary citizens, subjects, and workers in the context of events related to the French Revolution. Fukuyama closely links the subsequent emancipation of man and his demand for an extension of his rights, especially the right to vote with the issue of thumos. According to Fukuyama, thumos is the driving force behind the democracy boom in the $19^{\text {th }}$ and $20^{\text {th }}$ centuries. The French Revolution and its related events have increased the feeling of importance in the broad masses of the population. Ordinary citizens have ceased to think of themselves as subjects who were passively accepting this role. The representatives of society's working class began to recognise themselves as a rightful part of the whole, which should be perceived and acknowledged by the surrounding environment. Enlightened rational reasoning caused equality before God proclaimed by the Church lost its universal legitimacy.

A continually growing number of the population gradually started to demand recognition or visibility towards society. A need, which in the traditional community was a privilege of warriors and heroes, started to emerge in this social segment. The unsatisfied thumos in the majority of society began to awaken. People who were previously perceived as lower-ranking citizens began to demand a privilege that previously only belonged to a selected minority. Ordinary citizens, to some extent, wanted to feel equivalent to the „nobility“. However, the equality of all members of society is apparently unreachable and undesirable for the ruling elite. It's hard to imagine how a class possessing movable and immovable assets shares their equity with subjects to achieve equality. This thumos demand was satisfied by the gradual extension of the right to vote and the establishment of democracy. Therefore, the broad spectrum of society felt recognised as a whole, and the same rights allowed all strata of society to satisfy their internal pride, as the ordinary citizen felt equal to the traditional elite before the law.

From the above, it may seem that liberal democracy is the most appropriate instrument to satisfy the requirements of the human soul. A liberal-democratic 
consumer society based on economic liberalism can satisfy human desires based on material saturation. Individuals desire material goods, and in order to achieve them, they strive to increase their wealth. Simultaneously, they help to maintain the economic cycle and contribute to the wealth of states. On this basis, materialism and all-encompassing marketing, typical phenomena for Western liberal-democratic capitalist societies, saturate both human aspirations and the economic prosperity of states. With exaggeration, we can say that not the „inextricable hand of the market, " but the material human desires are the primary driving force of the market economy.

At the same time, liberal-democratic Western societies provide space for the satisfaction of human reason. Modern Western society has grown based on the primacy of human reason, which to date, has developed a great deal in many ways. Scientific advancement, new scientific disciplines, an emphasis on education and its social prestige, a virtually unlimited supply of literature, an endless variety of information and easy access to it are typical features of today's Western society. The reasoning part of Plato's human soul has, therefore many variations for application. Nevertheless, it's complementary to human desires through materialism.

Finally, a liberal-democratic society reflects human thumos through equal suffrage and universal equality before the law. Citizens of liberal-democratic societies feel equality regardless of their socio-economic status. The voice and rights of workers have the same weight as the voice and rights of elites, soldiers (former warriors) or politicians. Therefore, human thymus should be saturated through these mechanisms in such societies. However, $20^{\text {th }}$ century events and the problems faced by liberal democracy at the beginning of the $21^{\text {st }}$ century point to the fact that this hypothesis has considerable flaws. Francis Fukuyama presents with an explanation of why this is the case. The assumption of the saturation of thumos in a liberal-democratic society could be true if thumos were universal in all people.

However, Fukuyama emphasises that thumos falls into two groups. The first group is defined as isothymia. Isothymia occurs in individuals whose need is to be recognised as equal to other members of society. It's associated with concepts such as solidarity, belonging, humanism, consensus, etc. Isothymia isn't radical and is usually found in societies. The second component is megalothymia. Unlike isothymia, it's present in individuals whose need is to be superior to others.

The second group is less represented in society and is demonstrated by Fukuyama on individuals who appear in positions of power, politicians, managers, top athletes, show-business stars, etc. Fukuyama attributes the pathological form of megalothymia to authoritarian leaders such as Adolf Hitler, Napoleon Bonaparte, or at present Vladimir Putin, but to some extent also Donald Trump and others. The common denominator of pathological megalothymia is the need to control others. Fukuyama is aware of the risks arising from the interaction 
of these various thumos forms and points out that recent years have shown that liberal democracies have failed to satisfy both groups.

Liberal Democracy provides the means of satisfying Megalothymia such as climbing 8,000 metre peaks, achievements in sports, business, art, politics, etc., but it doesn't allow the "pathological“ form of megalothymia that is present in individuals hankering after absolute power over others, present in individuals with authoritarian tendencies, according to Fukuyama also in Viktor Orbán in Hungary, Jaroslaw Kaczynski in Poland and others. That is, in countries where there is a tendency against the 1990s liberal-democratic assumption. Megalothymia is one of the threats to liberal democracy.

However, in the book Identity, Fukuyama especially examines problems associated with Isothymia. Fukuyama divides society into groups based on their identity, which is closely associated with thumos. It puts forward the hypothesis that the current political struggle isn't a struggle of classes or a struggle for a redistribution of resources from the Treasury, but a struggle of identities. It's the dissatisfaction of the different identities and their representatives that is the cause of the problem in today's liberal democracy. Fukuyama emphasises that the various segments of society (identity) feel overlooked or disadvantaged by the elites and the rest of society. Therefore, these identities feel inferior to the whole; they feel frustrated, believing that someone has the rights that „naturally“ belong to them. Although their rights are guaranteed by a liberal-democratic constitution and their electoral vote has the same weight as anyone else's. However, this means that as a product of enlightenment, it's no longer sufficient to satisfy their thumos. In this way, their isothymia isn't satisfied. Groups of citizens who feel that someone (another group, government, etc.) has stripped them of their rights, and they consequently demand the recovery of their rights. Yet in most cases, this feeling is irrational, as in fact, their rights were not deprived. However, there is a phenomenon that various other minority identities, which had previously rights in some way different, succeed in gaining equality with other identities.

A similar phenomenon also occurs vice versa. Formerly marginalised identities feel disadvantaged against other identities and claim equality. This leads to a vicious circle, letting out different identities yet frustrated in the same way. They feel neglected by the system at the expense of other identities. According to Fukuyama, identities outperformed national identity. Identity members feel a stronger community than a national community. Therefore, it's not an international-level dispute, but a national dispute. National unity, face to face unity of identities, is weakening considerably and ceases to play the role of a sealant regulating disputes between different segments of state citizens. In many cases, identity requirements are internationalised, with identities with similar or similar interests getting interconnected across states, disregarding their own citizenship, and opposing their governments and other identities. 
Identities are formed by the same requirements, lived and shared experiences, problems, also often racial, religious or ethnical. Fukuyama affords particular mention to the lived experience phenomenon as essential in creating identities. Different groups have taken different historical paths whereby they've experienced and shared experiences at the „intergroup“ level. Through this lived experience, different requirements of different groups are formed. For example, despite today's racial equality, it's clear that the American black minority views its rights in a different way than the white majority. (Fukuyama, 2018: 110)

It's evident that within liberal-democratic states adopting multiculturalism, lived experience is not homogeneous among all their citizens. Heterogeneity and diversity are typical of Western societies. The same applies to different intranational group segmentation. In many cases, rather than a lived national experience, different groups within the state feel a lived group experience that's projected into the construction of their identities. This creates a large number of groups within the state that have different or opposite requirements and are linked by a deviation from the mainstream in different directions. Fukuyama describes the concept of identity based on the concept of Jean-Jacque Rousseau; that is, identity is not innate but is formed by experience, external factors, perceptual perception, and learning throughout life. Fukuyama mentions left-wing activists fighting for the emancipation of minority rights (LGBT ${ }^{14}$, Black Lives Matter ${ }^{15}, \mathrm{MeToo}^{16}$, etc.) as examples of identities, as well as right-wing nationalism and religious fundamentalism. On this basis, Fukuyama is rethinking the established understanding of left and right wings. (Fukuyama 2018: 103 - 123)

While in the past, the right-left struggle was characterised on an economic basis, at present, this conflict is, according to Fukuyama, manifested by a struggle of identities. Understanding the left and right is now very different from its traditional concept. Fukuyama mentions that this change originated in the 1960s and 1970s when the origins of the policy of identities began to form in Western Europe and the US. The 1960s and 70s are characterised by an increase in many social movements, defined in their demands vis-à-vis the establishment, government decisions, or the system as such. Many of these minority movements were connected by the demand for being socially recognised and gaining equality with the majority of society. The most common themes of these movements were immigration, the status of women, the environment, etc. (Fukuyama 2018: 106). As an example, we can mention the so-called „1968 Generation“, which brought together young people across Western Europe.

14 Available online at: https://www.aclu.org/issues/lgbt-rights, https://www.hrc.org/, https://ggbt.foundation/who-were-here-for (24 February 2020).

15 Available online at: https://blacklivesmatter.com/ (24 February 2020).

16 Available online at: https://metoomvmt.org/ (24 February 2020). 
The various „1968 Generation“ movements identified themselves as the left, but instead of a class war, they were mentioning the rights of various minority groups. It's these events that laid the foundations of the modern conception of left and right (Rootes 2008: 295 - 305). The left-wing demands following the emancipation of various minorities and the change in the political and social status quo came with a right-wing response in the position of advocating traditional values and the social status quo.

On this basis, according to Fukuyama, the present conception of the left and right is formed, which has been polarised by significant events of the first two decades of the $20^{\text {th }}$ century into today's form of policy of identities. Simultaneously, traditional voters of the left-wing now tend to incline to the right one and vice versa. At the present, the left is represented by progressive, often post-modernist groups that promote minority emancipation, a liberal approach to migration, post-material values, etc., while the right is a conservative advocate of the status quo, the nation state, and exclusivity of indigenous people, the standard concept of family, Christian values, and in extreme terms it refers to ethnic or racial origin.

With this assumption, the working class moves, from its position as the voter, from the left to the right as it defends order and the system known to it, while the progressive left ceases to understand this segment of society. In the case of Fukuyama's approach to shifting voters from the right side of the political spectrum, and vice versa, it's possible to find similarities to R. Ingelhart's concept. As early as the early 1990s, R. Ingelhart came up with the idea that in developed and modern western states, the working class was approached by right-wing leaders defending the status quo and conservative national values against globalisation progress, while traditional right-wing voters in the environment of the country's „welfare“ after reaching the economic saturation voted for left-wing parties promoting post-material values (Inglehart 1990: 5 - 11). With regard to the above stated, it's clear that the approaches of both researchers are based on the same hypothesis, i.e. shift of voters to the other side of the political spectrum. However, the difference lies partly in the cause of this process, while Inglehart mentions economic principles, such as economic saturation, Fukuyama's approach is based on identity and thumos.

The common feature of these groups of identities is the feeling that they are deprived of the rights that they own. They feel neglected by society, elites, or the outside world, which don't seem to see their problems. These groups have antipathy towards other groups that „steal“ their rights. The clash of identities in Fukuyama's presentation represents a conflict of opposing groups whose goal is identical - the accomplishment of their own thumos, but the concept of this goal is different or contradictory for each group. Therefore, a large number of groups with different requirements arise within states, seeking different and often diverse goals and requirements. This national heterogeneity consequently harms the stability of the democracy of the states in question. 
In Fukuyama's approach to the fragmentation of the social spectrum concerning the stability of democracy, it's possible to find some common elements with the typology of Gabriel Almond's democratic systems, which Almond introduced in 1956 (Almond 1956). Almond describes four types of political systems: the Anglo-American political system (including Commonwealth countries, USA), the continental European system (without the Scandinavian and Benelux countries combining elements of the European continental and Anglo-American systems), pre-industrial or semi-industrial political systems occurring outside of Europe. North America and totalitarian political systems. Of particular interest to our needs are the first two types of G. Almond, i.e. the Anglo-American and European continental systems (Almond 1956: 392 - 393).

Almond argues that the Anglo-American system shows greater stability of democracy than the European one. Almond bases this assumption on the greater degree of homogeneity of political culture and social cohesion, which he believes is shown by states such as the United Kingdom and the United States, while strongly heterogeneous European societies show signs of less democratic stability (Almond 1956: 392 - 393). It's in this statement that one can observe certain similarities with Fukuyama, that is, the greater the homogeneity of society, the more stable the state's democracy. It's the strong heterogeneity and fragmentation of society that Fukuyama considers as one of the reasons causing the issues that democracies have been facing in recent years.

The difference between Fukuyama's and Almond's research largely lies in the variables that both researchers focus on. While identity is the key for Fukuyama, Almond focuses on political culture. Yet, both explore similar phenomena in different ways, i.e. social fragmentation or cohesion. Nevertheless, their conclusions are different, and Almond's hypotheses does not apply to Fukuyama's research. Almond argued that the Anglo-American system showed more stability for its homogeneity than socially fragmented political systems in continental Europe, while Fukuyama points out the fragmentation of society into many different identities in both the United States and Europe. Democracy is confronted with similar problems on both continents of the Western world. Therefore, Almond's typology isn't valid in Fukuyama's approach.

A common phenomenon that is present in both the US and EU countries is right-wing nationalism, described as a "white man revolt“. This identity is represented predominantly by lower-ranked individuals on the socio-economic ladder, and its members also belong to long-term citizens of a given state with a family tradition of citizenship who see themselves as rightful citizens of that state. In recent years, this group has come to the belief that elites are advocating for minority rights more and more, have forgotten the "white man“ and that his voice has stopped being heard in "his“ country. This group, defending the conservative organisation of society, ceases to understand the „post-modern world“, and „is getting lost“ in it, and therefore is supporting the right-wing 
nationalist leaders who speak "their" language and provide the representatives of these groups with an understanding of the world. The requirement of this group is furthermore to return to the "good old days", but this time it's often unspecified and therefore represents a construct of the myth of the "good old days". The most demonstrative example of this phenomenon is Donald Trump being elected as the president of the United States with the slogan „make America great again" ${ }^{\text {17. }}$.

Other identities described by Fukuyama lie on the left side of the political spectrum and are represented by groups defending the rights of various minorities and post-material or postmodern values. Examples include various LGBTQ community rights movements ${ }^{18}$, Black Lives Matter movement ${ }^{19}$, MeToo campaign $^{20}$, environmental movements, and more. The common denominator of these groups is the feeling of inequality as compared to the rest of society and the consequent demand for more rights and for their voice to be heard. Right-wing and left-wing identities naturally come into conflict without the ability to find consensus, since their discourse is very different. According to Fukuyama, the apparent cause of this dissatisfaction is the unfulfilled requirement of the thymus of the representatives from the given identities.

Another common feature of these identities is that the representatives unfolding animosity of individual identities poses a threat to liberal democracy in the Western world. Based on Fukuyama's analysis, it can be argued that the policy of defining identities is behind the problems that liberal democracies are facing. The litmus paper regarding the difference between the right-wing and the left-wing identities is their different view on the issue of migration. While the left has a positive attitude to migration, the right is more sceptical about it and in many cases even dismissive or hateful. However, there are several of such split between identities. The incompatibility of the requirements of individual segments leads to their radicalisation on both sides, thereby emptying the central segment, which has the potential for a consensual solution and simultaneously forms the backbone of liberal democracy.

Fukuyama's identity groups further include religious fundamentalism demonstrated on the example of Islamism in Europe. Fukuyama believes that Islam, like religion itself, isn't the cause of the crimes in Europe by Islamic radicals. Fukuyama argues that the cause of this issue is the radicalisation of the second to the third generation of Muslim immigrants whose parents have accepted coexistence with Western culture. Their children aren't raised to hate Western

17 Available online at: https://www.politico.com/blogs/donald-trump-administration/2016/12/trumps-inaugural-slogan-make-america-great-again-232414 (24 February 2020).

18 Available online at: https://www.aclu.org/issues/lgbt-rights, https://www.hrc.org/, https://gbt.foundation/who-were-here-for (24 February 2020).

19 Available online at: https://blacklivesmatter.com/ (24 February 2020).

20 Available online at: https://metoomvmt.org/ (24 February 2020). 
culture; the origin of their hate isn't finding their own position in society. The minority Muslim community in Europe doesn't provide these youngsters with their identity, as it's unable to compete with the competition of the Western lifestyles in Europe, and its potential is becoming somewhat emptied. However, at the same time, young Muslims who, as a disadvantaged minority, mature into a society where they don't find their place and don't fulfil the sense of equality or respect, i.e. thumos fulfilment, are subsequently prone to radicalisation provided by the propaganda of radical Islamist groups. The same phenomenon of frustration among young representatives of Muslim minorities is described by many other authors, such as Robinson et al. in Muslim youth in Britain... (Robinson 2017: 266 - 289). Many of these young people unexpectedly disappear from their parents and are „recruited“ by Islamist groups, where, based on indoctrination, they feel the fulfilment of their own pride and superiority to others, i.e. the fulfilment of thumos to megalothymia. The origin of this radicalisation again comes from thumos.

After analysing the causes of identity issues, Fukuyama comes up with a potential solution. Fukuyama sees strengthening national identity as the starting point for this issue, as this would be the connecting tissue of national unity on fundamental issues. Fukuyama doesn't propose to homogenise society and break down different identities but stresses the role of the state, which should give its citizens a sense of belonging. Liberal-democratic institutions should be the foundation of liberal-democratic societies. Therefore, to some extent, Fukuyama gives precedence to Western culture over others by arguing that immigrants to Western countries must accept Western culture as dominant in the given region, respecting its rules and not developing parallel rules, which are not congruent with liberal democracies.

Therefore. the task of political leaders should be strengthening society's confidence in liberal-democratic institutions and values and especially, their clear definition. This should create imaginary states' pillars in which citizens can believe and refer to them. According to Fukuyama, the foundation of societies shouldn't be their diversity as such, but instead, they should find the values and principles that create the connective tissue across identities. It's not his intention to completely empty conflicts between identities, but this conflict must be subdued by common foundations in such a way that it isn't a threat to the stability of a liberal-democratic system. It is a national identity that should serve as a „connective tissue “ for society and consensual space for constructive resolution of conflicts across identities. Fukuyama analyses the EU Member States individually, as well as the US and others, but doesn't reject the idea of finding a collective European identity and establishing a European Federation.

Fukuyama's approach towards the construction of national identity resembles the concept of a "melting pot“ (Hirschman 1983: 379 - 423). Western culture and its liberal-democratic institutions and the market economy in the 
respective states should be maintained as dominant, as in Fukuyama's opinion, these are behind the success of the West. Therefore, national identity in Western countries should be constructed on a consensual and broad liberal-democratic basis. Other identities should be preserved, but shouldn't exceed the dominance of a national identity, which should be respected by all citizens of states regardless of their allegiance towards other identities. Therefore, to a certain extent, national identity represents a national unity in fundamental issues that suppresses conflicts between other identities. For example, under this assumption a Muslim in the Parisian suburbs, a Parisian feminist, a heterosexual right-wing nationalist from Calais, an African immigrant working in Nice, a homosexual man from Lyon or an Eastern-European worker should be able to accept French identity and share its values or norms through citizenship without significant hurdles, while preserving their own diversity, but living together as equal Frenchmen without major conflict ${ }^{21}$. According to Fukuyama, the prerequisite for such a situation is acceptance and trust in national liberal-democratic institutions and laws.

According to Fukuyama, the topic of migration shouldn't be polarised, as is the case today in many circumstances. Fukuyama doesn't see the solution to this issue in building walls, altogether banning migration or on the contrary, a completely unregulated liberal approach to migration. Both these radical positions and their abuse by populist politicians on the right and left prevent a genuinely constructive and integral solution to the issue. The way to solve the immigration issue should be the efforts of states to assimilate better and integrate those arriving into the dominant culture of the respective state. However, this integration can't take the form of a coercive or violent path, but rather through the motivation of migrants to participate in the established system of the given state and accept its dominant culture. This motivation should be supported in terms of facilitating access to jobs, offering public service positions, or integrating children into mainstream schools to minimise the risk of social exclusion and the forming separate closed communities for ghettos that are not compatible with the dominant culture.

On this principle, the majority of society shouldn't close itself to minorities living in the territory of a given state. The state should endeavour to include representatives of minorities into the structures of the majority society. An individual moving in a society without a sense of belonging to it and a sense of inappropriateness is prone to radicalisation not under his faith. The cause of his radicalisation is the non-fulfilment of requirements of his thumos, which leads to a problematic perception of his own identity. In this case, the state should play a crucial role and seek to motivate the representatives of minorities to integrate into its socio-economic system structures. As described above,

21 Example created by the author of the review. 
the state should provide minority representatives with the possibility of self-identification through a sense of belonging to the whole and own competitiveness based on good access to work and social opportunities. The sense of belonging to the whole is to be built upon the acceptance of the national liberal-democratic identity, the construction of which is the state's responsibility. (Fukuyama 2006)

Fukuyama's book Identity: The Demand for Dignity and the Politics of Resentment can be understood as a free continuation of his previous work and simultaneously as its defence. It's evident that Fukuyama continues in the normativeness of liberal democracy as in the ideal of the political and social order of modern states. He recognises the shortcomings and risks of liberal democracy, but instead of trying to overcome it, he attempts to analyse its problems. At the same time, he's trying to find a solution to the problems of liberal democracy. This publication may be seen as a handbook for contemporary political leaders in the Western world and a guide on how to unify rival identities. At the very end of the book, Fukuyama emphasises that Identity can serve to division, but it can also serve for integration. Moreover, this is ultimately a remedy for populist politics today ${ }^{22}$.

\section{Literature and electronic resources used:}

Almond, G. A. (1956): Comparative Political System In The Journal of Politics, Vol. 18, No. 3, pp. 391 - 409. Available at: http://www.jstor.org/pss/2127255,

Fukuayama, F. (1989): The End Of History In Center For The National Interest, The National Interest, No. 16 (Summer 1989). 3-18. Available at: https://www.jstor.org/stable/24027184

Fukuayama, F. (1991): Liberal Democracy as a Global Phenomenon In Political Science \& Politics, č. 24, v, 4, s. 659-664. doi:10.2307/419399

Fukuayama, F. (1992): The End Of History And The Last Man. New York: Free Press. $418 \mathrm{~s}$. ISBN 0-02-910975-2

Fukuayama, Francis (2006): Identity, Immigration and Democracy" In Journal of Democracy 17(2). Fukuayama, FRANCIS (2018): Identity: The Demand for Dignity and the Politics of Resentment. New York: Farrar, Straus and Giroux. 240 s. ISBN 0374129290

Hirschman, CH. (1983): America's Melting Pot Reconsidered. IAnnual Review of Sociology 9: 397-423.

Huntington, S. (1997). Clash of Civilisations and the Remaking of World Order. New York: Simon and Schuster. 368 s. ISBN 9780743231497.

Inglehart, R. (1990): Culture shift in advanced industrial society. Princeton: Princeton University Press, 484 s. ISBN 0691022968.

22 FUKUYAMA, FRANCIS (2018): Identity: The Demand for Dignity and the Politics of Resentment. New York: Farrar, Straus and Giroux. s. 183 ISBN-10: 0374129290 
Platón (1993): Ústava. Praha: Svoboda-Libertas, 528. ISBN 80-205-0347-1.

Robinson, L.; Gardee, R.; Chaudhry.,F.; Collins, H. (2017): Muslim youth in Britain: Acculturation, radicalisation, and implications for social work practice/training. Journal of Religion \& Spirituality in Social Work: Social Thought 36(1-2): 266-289. DOI: 10.1080/15426432.2017.1311244.

Rootes, C. (2008): The Environmental Movement. In Klimke M., Scharloth J. (eds) 1968 in Europe. New York: Palgrave Macmillan, s. 295 - 305, ISBN 978-0-230-61190-0.

E-International Relations (2018): Huntington vs. Mearsheimer vs. Fukuyama: Which Post-Cold War Thesis is Most Accurate? Available at: https://www.e-ir.info/2018/04/22/huntington-vs-mearsheimer-vs-fukuyama-which-post-cold-war-thesis-is-most-accurate/ (24 February 2020).

Freedomehouse.org. (online): Modern Authoritarianism and Illiberal Democracies. Available at: https://freedomhouse.org/report/modern-authoritarianism-illiberal-democracies (24 February 2020).

Politico.eu (2016): Is Poland a failing democracy? Available at: https://www.politico.eu/article/ poland-democracy-failing-pis-law-and-justice-media-rule-of-law/ (24 February 2020).

Guardian.com (2018): Italians first': how the populist right became Italy's dominant force. Available at: https://www.theguardian.com/world/2018/dec/01/italians-first-matteo-salvini-the-league-rise-rightwing-populism (24 February 2020).

Usnews.com (2018): Austria's influential rise to fuel far right movement in Europe. Available at: https://www.usnews.com/news/best-countries/articles/2018-07-05/austrias-influential-rise-to-fuel-far-right-movement-in-europe (24 February 2020).

Forreignaffairs.com (2018): How Russia and China Undermine Democracy. Available at: https://www.foreignaffairs.com/articles/china/2018-10-02/how-russia-and-china-undermine-democracy (24 February 2020).

Washingtonpost.com (2018): China - Authoritarian regime. Available at: https://www.washingtonpost.com/gdpr-consent/?destination=\%2fnews\%2ftheworldpost $\% 2$ fwp $\% 2 f 2018 \% 2 f 11 \% 2$ f27\%2fchina-authoritarian\%2f\%3f \& utm_term=.d58e2ed0138d (24 February 2020).

Foreignpolicy.com (2019): Understanding Trump's Trad eWar. Available at: https://foreignpolicy. com/gt-essay/understanding-trumps-trade-war-china-trans-pacific-nato/ (24 February 2020).

Independent.co.uk (2018): Putin says new US sanctions on Russia are 'senseless'. Available at: https://www.independent.co.uk/news/world/americas/us-politics/us-russia-sancions-latest-putin-trump-washington-moscow-a8503371.html (24 February 2020).

Forignpolicy.com (2018): New Sanctions Won't Hurt Russia. Available online at: https://foreignpolicy.com/2018/09/26/new-sanctions-wont-hurt-russia-putin-oligarchs-rusal-deripaska/ (24 February 2020).

Classicalwisdom.com (online): Thumos according to Plato". Available at: https://classicalwisdom. com/culture/traditions/tradition-thumos/ (24 February 2020).

Aclu.org (online): lgbt rights. Available at: https://www.aclu.org/issues/lgbt-rights. (24 February 2020).

Hrc.org. Human Rights Campaign. Available at: https://www.hrc.org/ (24 February 2020). 
Lgbt.foundation. Who We're Her eFor. Available at: https://gbt.foundation/who-were-here-for (24 February 2020).

Blacklivesmatter.com. Black Lives Matter. Available at: https://blacklivesmatter.com/ (24 February 2020).

Metoomvmt.org. Me Too Movement. Available at: https://metoomvmt.org/ (24 February 2020).

Politico.com (2016): Trump's Inaugural Slogan - Make America Great Again. Available at: https:// www.politico.com/blogs/donald-trump-administration/2016/12/trumps-inaugural-slogan-make-america-great-again-232414 (24 February 2020).

František Padour, M.A. is a PhD Candidate in Politics at the Metropolitan University Prague.E-mail: padof9ax@student.mup.cz 